\title{
Queering the Nigerian Cinema and Politics of Gay Culture
}

\author{
Stephen Ogheneruro Okpadah \\ Lecturer \\ Department of the Performing Arts \\ University of Ilorin, Ilorin, Nigeria \\ Email: okpadahstephen@gmail.com
}

Submitted: September 22, 2018/Accepted: November 3, 2020 / Published: January 28, 2021

\begin{abstract}
The advocacy for gayism and lesbianism in Nigeria is informed by transnational cultural processes, transculturalism, interculturalism, multiculturalism and globalisation. Although critical dimensions on Lesbian, Gay, Bisexual and Transgender (LGBT) are becoming recurrent subjects in Nigerian scholarship, scholarly works on LGBT, sexual identity and Nigerian cinema remain scarce. Perhaps, this is because of indigenous Nigerian cultural processes. While Chimamanda Adichie, a Nigerian novelist cum socio-political activist, campaigns against marginalisation and subjugation of gays and lesbians and for their integration into the Nigerian cultural system, numerous African socio-cultural and political activists hold a view that is dialectical to Adichie's. The position of the members of the anti-gay group was further strengthened with the institution of stringent laws against gay practice in Nigeria by the President Goodluck Jonathan led government in 2014. In recent times, the gay, bisexual, transgender and lesbian cultures have been a source of raw material for filmmakers. Some of the thematic preoccupations of films have bordered on questions such as: what does it mean to be gay? Why are gays marginalised? Are gays socially constructed? What is the future of the advocacy for gay and lesbian liberation in Nigeria? Although most Nigerian film narratives are destructive critiques of the gay culture, the purpose of this research is not to cast aspersion on the moral dimension of LGBT. Rather, I argue that films on LGBT create spaces and maps for a critical exploration of the gay question. While the paper investigates the politics of gay culture in Nigerian cinema, I also posit that gays and lesbians are socio-culturally rather than biologically constructed. This research adopts literary and content analysis methods to engage Moses Ebere's Men in Love
\end{abstract}


with reference to other home videos on the gay and lesbian motifs.

Key Words: Gay, lesbian, transgender, bisexual, queer, LGBT, Nigerian cinema.

\section{Introduction}

Homophobia in Africa is made up of national differences both in extent and intensity of antihomosexual laws and legislations (Sirvirtson, 2016, p. 11).

The support for gays and lesbians in Nigeria is as a result of transnational cultural processes and globalization. As societies continue to be in a constant flux over time as new spaces are being created, and as the global continue to converge with the local, new sexual identities will continue to emerge. The term homosexual was coined by Karl-Maria Kertbeny in 1868 to describe same-sex sexual attraction and sexual behavior in humans (Kertbeny, 1869, p. 1). While some scholars refer to those who indulge in one sexual activity or the other of the same sex as homosexuals, others believe the term should refer to males who engage in it. Hence, the appropriation of the term lesbianism to situate females who are emotionally and sexually attracted to people of the same sex.

The term queer is a conglomeration of sexual categories such as lesbianism, gayism, bisexualism, transgenderism and other non-conventional sexual orientations. With the continuous emergence of new sexual processes, the term queer is in a constant state of flux. How are gay communities constructed? Are they biologically or socially created? In Homosexuality: biologically or environmentally constructed, Thompson and Devine (1998) argue that most homosexuals are biological constructions. In their words, "homosexuality among humans is a biological construction which is found innately in some people... it is a healthy biological form of sexual expression which in no way deviates from the natural evolutionary process 
of human sexuality." (p.1). The authors posit further that "half of the identical twins of homosexual men are themselves homosexuals, proving such genes might exist". We must understand that using twins as a paradigm is fallacious with the fact that twins tend towards acquiring identical behaviour. They tend towards possessing identical trait.

There is a dearth of critical works on LGBT, sexual identity and the Nigerian cinema. Twenty-first century Nigerian cinema has begun to explore the LGBT condition. While most films on LGBT in Nigeria are critical of LGBT practices, I do not intend to approach the study in the context of morality. Instead, I contend that these films create spaces for scholarly/ critical explorations and evaluations of the LGBT condition in Nigeria. Also, this paper refutes the assertion that some people are born gay. In other words, I dismiss the biological gay theory. I examine politics of gay culture in Nigeria and hypothesize that lesbians and gays are socially and culturally constructed. In other words, they are not genetically/biologically made. I engage Moses Ebere's film Men in Love as well as other home videos on gay and lesbian motifs in my analysis.

\section{Theoretical Framework}

The paper is anchored on Judith Butler and Eve Sedgwick's perspective of queer theory. According to Butler and Sedgwick, identities are the effects of institutions, practices, and discourses, regulatory fictions that are reiteratively produced and sustained through a series of social performances. Sedgwick seeks to show the political and discursive stakes in the establishment of a sexuality based binary in order to suggest that this binary, likewise, can operate as a regulatory fiction (Cover, 2001, p.73).

The queer is the unreasonable, the absurd, the illogical, the incoherent and the questioned. Butler and Sedgwick approach the queer from the dimension of culture. To Butler, traditions and institutions are what are used to measure or determine identity 
(sexual identity inclusive).

Queer theory is beneficial for understanding the construction of notions of sexuality that go beyond ideas of the natural - ideas of a genetic and fixed set of sexual categories in opposition - and for understanding and actively opposing notions of sexuality and sexual labeling that are simplistically and discursively reduced so as to ignore the role in sexualitybased description and identity construction that are played by notions of time, space, need, material condition, and class demarcations - in other words, desire not grounded in genderobject-of-choice (Cover, 2001, p.72).

Queer construction theory is also in the domain of the oppressors and the oppressed, the dominant class and the marginalised. It is in the spectrum of politics of hegemony and dominance of a mainstream culture over a minor group that stands as counterculture to the mainstream culture. The question of power tussle between the heteronormativity and homosexualtivity binary gives queer theory a political foundation. It also brings to bear Michel Foucault's theory of power, knowledge and discourse.

\section{Queer Culture in Nigeria}

Now I reactivate my fight in defence of the LGBT community. You know something? Openness may not completely disarm prejudice but is a good place to start. I am hoping that my support will be a show of strength to the Nigerian LGBT \& community (Charles Oputa alias Charley Boy, in support of his daughter's new found non-straight sexual orientation).

The above statement fully captures a society where the right of gays and other sexual constructions are being subdued. Homosexual acts contravene the moral, cultural and religious ethos in Nigeria. Heterosexuality dominates the sexual landscape. 
The criminalisation of the gay community can be traced back to pre-colonial times. Precursory to the amalgamation of the Southern and Northern Protectorates, the various kingdoms that existed in the geographical orbit meted punishments such as banishing of gay partners, ritual propitiations, payment of fines among others on those found guilty of homosexual practices" (Novak, 2018, p. 71). The criminalisation of LGBT was further energised with its illegalisation in more recent times.

On 7 January 2014, Nigerian President Jonathan Goodluck signed his assent to the Same-Sex Marriage (Prohibition) Act, 2013 (SSMPA). Several elements of this legislation contravene Nigeria's Constitution as well as its binding international obligations, which guarantee fundamental rights to dignity, equality, non-discrimination, privacy, freedom from arbitrary arrest and detention and freedom of expression and association. Under pre-existing law, Nigeria already criminalises consensual same-sex sexual activity in private which attracts a maximum penalty of 14 years imprisonment This action generated destructive criticism from various quarters (Human Dignity Trust 2013, p.1).

Leading creative artists of Nigerian descent such as Charles Oputa (Charley Boy), Helon Habila and Jackie Kay, in numerous symposia, conferences and seminars, have criticized the Nigerian anti-homosexual law and called for its repeal. Adichie's manifesto against the anti-homosexual law reads thus: The new law that criminalises homosexuality is popular among Nigerians. But it shows a failure of our democracy, because the mark of a true democracy is not in the rule of its majority but in the protection of its minority... holy books of different religions do not have equal significance for all Nigerians but also because the holy books are read differently by different people. The Bible, for example, also condemns fornication and adultery and divorce, but they are not crimes (Adichie 2014, p.1).

While this research is neither an advocacy for gayism nor to cast destructive aspersion on the moral dimension of 
LGBT, it is pertinent to note that Adichie's position brings to the fore a prominent point on the acceptability and nonacceptability of the gay question. Most advocates of the antihomosexuality law do so from the standpoint of culture and religious precepts. Paradigmatically, the Holy Bible of the Christians see homosexual practice as anathema. If we must make national laws, must they be made in tandem with the religious coda? In Christianity, no sin is greater than the other. Any sinner who commits murder will end up in the same hell fire as one who steals, gossips or lies. Why then do fornication and adultery not attract the same fourteen years imprisonment as homosexuality does? We must also remember that Nigeria is a secular state and a multi-dialectical nation with numerous ethnic groups, ideological beliefs, religions, among others and as such is prone to diverse cultural practices.

The criminalisation of LGBT has made the gay community subaltern in their own societies. Professor Wole Soyinka also charted the same course as Habila, Kay and Adichie in criticising the clamp down on homosexuals' human right. The crux of the manifesto of advocates of the right for homosexuals, is that "Nigeria should instead aspire to be counted among the civilised nations where respect for individual and human rights is paramount" (Okuefuna, 2016, p.48). The challenge on mainstream values by LGBT attests to the fact that society is in a constant state of flux.

As a counterculture to straight/heterosexuality, homosexuality still continues to thrive in Nigeria. In 2016, in Ondo state, Nigeria, a young man, Akinnifesi Olubunmi died from being beaten by a mob that caught him making love to another man. There is also another instance of jungle justice against gays recorded somewhere in Nigeria in December 2013, although unverified, wherein two alleged gay men who were said to have been caught in a homosexual act were beaten to death" (https://www.naij.com/763127-shocking-gay-manbeaten-death-ondo-state-photo.html). 
In recent times LGBT practices have become issues of discussion in Nigerian films. Two categories of LGBT cinemas that exist are those that valourise its practice. The second category comprise films that project gayism, lesbianism, bisexualism and transgenderism in a negative light. Although most Nigerian film narratives are in the second category, the films create spaces and maps for a critical exploration of the gay question by the Nigerian populace. It is against this backdrop that the next section of this paper investigates gays and lesbians as social constructions. It engages Moses Ebere's Men in Love as a reference point to examine politics of gay culture in Nigeria.

\section{Synopsis of Men in Love}

In Men in Love, Charles (John Dumelo), an accomplished businessman with a wife, Whitney (Tonto Dike) and a son, gets involved in philandering. He goes to a hotel with his female secretary who was recommended to him by Whitney. The wife who gets to know, goes to the hotel and catches them red handed as the secretary is in her panties trying to take off Charles clothes. Out of jealousy and anger, Whitney beats up the secretary, breaks the bottle of wine, stabs her on the back and storms out. That same evening, Charles returns with a blood stained shirt, and makes straight to the bedroom. He accuses Whitney of almost committing murder and another brawl ensues. Charles asks for forgiveness soon after and they make love.

The following day, Charles leaves his house for his office, when he sees his long lost friend, Alex (Muna Obiekwe). They exchange pleasantries and Alex mentions his purpose of coming to Charles' company and he also insists they take a stroll. At the same time, back in Charles' house, his wife narrates his husband's ordeal to her friends, Flora and Zina. She however, tells them that Charles is very good in bed and they laugh over it. The following day in a hotel, Charles introduces Whitney to Alex. From then onwards, Alex becomes a close friend of the family. One day, Alex asks Charles' opinion on homosexuality 
and he realizes that the latter is neutral about it. At this juncture, Alex reveals that he is a gay and that he wants Charles to be his partner. Out of shock and anger, Charles storms out of Alex's house.

A few days later, Alex apologises for his proposal to Charles and invites him to his birthday party. With Whitney's support, Charles attends the birthday that night. He soon falls asleep and wakes up the following morning to see himself in Alex's bed, with only his shorts on. He realizes that he had been raped. Charles slaps Alex and promises to arrest him. After days of pondering, he returns to Alex to seek his forgiveness. He accepts Alex's proposal and buys a car for him. After some time, he packs into Charles' house on the pretext that his (Alex's) house is being renovated. Whitney, believing that Alex is a calming influence on Charles, allows him to move into their home. One day, Flora and Tasha are in a restaurant when they see Charles and Alex enter the restaurant laughing and holding each other. They even go to the extent of kissing in public. They refuse to tell Whitney because she will not believe them. During Charles' birthday celebration, he refuses to sew the same outfit with his wife, but he does so with Charles. Whitney storms out of the birthday party. It is at this juncture that Flora and Tasha tell Whitney what they saw the previous day. Realising that Alex and Charles are gay partners, Whitney goes to her house dazed. There is a cold war between Whitney and Alex. She tells Alex to leave her house but he refuses. Charles is neutral since he does not make any comment whenever they (Alex and Whitney) quarrel. One afternoon, Whitney who has been trying to call Charles on the phone without success barges into his office and catches him with Alex naked, making love. This being the crescendo of her patience, Whitney resorts to seeing a pastor who prays for her and Charles returns to her asking for forgiveness. 


\section{Politics of Gay Culture in Men in Love}

Men in Love does not reflect Nigerian cultural ethos and norms. In fact, gay practice is considered obscene and is looked at with contempt. This is what makes Alex beat around the bush in his bid to tell Charles that he is gay. He is reluctant to divulge his orientation on LGBT. Even after introducing and trapping Charles inside, they still make the act secret. This is fully captured in sequence seventeen where Charles sneaks into the visitor's room in which Alex spends the night, to make love with him. This action becomes recurrent. In extension of the perverted nature of homosexuality, there are also other explicitly obscene acts that are quite odd to the norms and ethics of the Nigerian society. The Nigerian and African cultural border is broken. According to Faith Olanrewaju, Felix Chidozie and Adekunle Olanrewaju in International politics of gay rights and Nigeria-US diplomatic relations, "a larger portion of the countries in Africa align themselves to the position that gay rights should not be condoned at all. According to Amnesty International, homosexuality is illegal in 38 of 54 African countries. African countries have a wide range of punishments for homosexuality" (505). However, in South Africa, "lesbian, gay, bisexual and transgender (LGBT) people enjoy the same rights as non-LGBTs" (LGBT goes to South Africa, 2020). The LGBT question has altered the definition of marriage which was traditionally known as the legal union of man and a woman to become husband and wife. With the prevalence of lesbian and gay marriage, this definition now dovetails into diverse sexual orientations.

Furthermore, in Men in Love, with the exposure of the naked parts of the bodies of the characters, one could not know where to differentiate the world of the screen from reality. In sequence two, Charles and his secretary are in a hotel room. The secretary takes off her trousers, exposing her brown panties, dark thighs and big buttocks. She pushes Charles onto the bed and begins undoing his belt when Whitney enters. Although this 
tends towards realism, it goes explicitly too far. This act is also captured in sequence twenty where Charles and Ale make love in the toilet in Charles' office. Charles' backside is exposed and part of Alex's pubic area showing.

Whitney does not suspect a romantic relationship between her husband and Alex because such an act is anathema. Although Charles lives a promiscuous life, it would not dovetail into his engaging in same sex sexual exploration. Whitney believes that Alex's meeting her husband has a positive effect on him (Charles). His promiscuous attitude had been watered down drastically. Hence, their friendship must continue. She even advocates Alex's moving into her house. But she is mistaken. Alex's sexual orientation is different from the mainstream sexual culture. He detests heterosexuality. Although his antecedent is not revealed in the video film, perhaps, Alex's sexual identity is influenced by his environment. Harsin (1991) makes the point that "most young men who are homosexual are not raised in an environment in which homosexual development is even recognised, much less encouraged. It is not unusual for men who have recently identified themselves as gay to not have any idea what being gay is all about" (p.31). Peer pressure is also germane to one's change in sexual orientation. Charles detests homosexuality. He expresses it when he storms out of Alex's presence when the latter proposes to him. After Alex's apology to him a few days later, he accepts him and their friendship continues. His continuous association with Alex, culminates into his becoming gay.

Charles's rape by Alex and subsequent acceptance of Alex's proposal, strengthens my argument that sexuality is a social construct. Even if signs of genetic creation of gayism abound, this cannot be fully appropriated. Advocates of the biologicality of LGBT orientation hinge their argument on Sigmund Freud's psychoanalytical theories such as Penis envy, Oedipus complex and Electra complex. With the decentering of Freud's above theories by modern critics, scholars such as Simon 
LeVay (1991) resorted to proving the geneticity of LGBT with the medium of biological experimentation. According to Ibanga (2017) Simon LeVay contends that "the brain of heterosexuals and homosexuals were different morphologically: The brain clusters was more than twice large in the heterosexual than in the homosexual" (p. 62). While LeVay's finding was gladly received by the gay community, "his study has been criticised for methodological errors including failure to adequately identify a controlled group, using a small sample group and taking samples from homosexuals who died of AIDS." (Ibanga, 2017, p. 62). The above seems to reveal the subjectivity of researches on the genetic dimension in sexual/gender construction. No man is born gay. Gays, lesbians and transgenders are made. They are not biological constructions.

Some environmental factors that constitute the choice of sexual identity are "childhood play patterns, early peer relations, differences in parental behavior toward male and female children, and gender constancy and stability" (Thompson and Devine, 1998, p.1). Suffice to state that a man marries a woman because he is born with the notion that he must marry a woman. The culture of heterosexuality is instilled in him as he grows up. Man is encultured in the tradition of heterosexuality. While heterosexuality is considered the norm, LGBT are questioned. In the researcher's undergraduate days, during a seminar presentation on homosexuality, a classmate of his (name withheld) affirmed that he was initiated into the gay enterprise when as a child of four years, he was assaulted by an older man. His environment and not a biological factor, therefore engendered his sexual orientation.

Charles frolics in his new found sexual engagement. The two of them (Alex and Charles) see the heterosexual tradition as abnormal. This brings to light the subjectivity of man's existence. With the upsurge of new sexual identities and orientations, the queer is becoming subjective. In the Unites States of America and most Western nations where homosexuality thrives, the 
queer question, to a large extent, has become or is becoming subjective especially with the integration of gays into the societal setup and the socio-cultural process. While heterosexuals see homosexuality as queer, the latter feel the sexual orientation of the former should also be questioned. This has created a counterculture to mainstream tradition. In Men in Love, Charles destructively criticises heterosexuality. He sees Alex as someone who has liberated him from a wrong sexual identity. He sees his transformation into a gay as the right choice. In fact, he is so comfortable with it that he kisses Alex in public and wears the same matching outfit with him. In sequence twenty, Alex, Charles's gay partner proves that he is Charles's new husband. In this scene, Charles who is prepared for work is offered food at the dining-table by Alex and Whitney at the same time. While Whitney glares at Alex to take his food away, the latter looks unconcerned. Charles continues to revel in his new found world that he does not protect Whitney, his wife from Alex's assault. In fact, he further compounds Whitney's woes when she catches him and Alex making love in his (Charles) office.

Despite the filmmaker's artistic and creative portrayal of gayism and its trend among friends in Nigeria and beyond, he is fully critical of the LGBT orientation. The cineaste isolates Alex and Charles in their own cocoon where all other characters in the video narrative are pitted against homosexuality. Although Whitney is a sexually active woman evidenced in her display of the erotic moments/scenes with her husband in some sequences in the video film, she does not advocate lesbianism and other queer dimensions. Her dislike for it is what sets the pace for the conflict in the narrative. Even Charles who is introduced into the gay cult by Alex later realises the shortcomings of such practice. At the end of the video film, Charles apologises to his wife and promises his wife to desist from his new sexual proclivities.

A Church pastor serves as a dues ex machina in the film. $\mathrm{He}$ is a metaphor for religion as anathema to the gay practice. In Islam and Christianity, the two prominent religions in Nigeria, 
homosexuality is anathema. This is one of the factors that has promoted the anti-gay tradition in Nigeria. After praying for Whitney, God touches her husband's heart and he returns to her requesting her to forgive him. The police also come into the scene to facilitate Alex's packing out of Charles's house. Sanity is restored in Charles's family as Alex leaves the house. This articulates the extent to which gayism, lesbianism, bisexualism and transgenderism are frowned upon in the society. Using Charles as a metaphor, the video narrative tells the LGBT community that it needs to have a rethink in its sexual orientations that contravene traditional sexual ethos. In other words, if sanity must be returned to the society, gays, bisexuals and lesbians must return to heterosexual practice. In addition, transgenders must neither distort nor dislocate their original sexual identity in other to facilitate an ordered and a balanced society.

\section{Conclusion}

Why am I gay? Why must I be placed at the margin because I am gay? What is the justification for the dominance of heterosexuality over homosexuality? These are the dominant questions queer studies seek to proffer answers to. As societies expand, as the world converge, as new cultures emerge, as the postnormal becomes normal, as old traditions give way to new trends to thrive, Nigerian societies still remain poised in their subjugation of homosexuality and new sexual orientations. Religion and indigenous cultural beliefs are also instrumental to the prevalent critical perception of gayism. Multiculturalism, transculturalism and globalisation have expanded the horizons of LGBT discourse and activism as creative artists such as Chimamanda Adichie, Wole Soyinka and Helon Habila among others continue to criticise the marginalisation and the subjugation of the gay community by pro-heterosexualists. The Nigerian home video film industry has been part of the advocacy for and against LGBT. While some video film narratives on the queer motif valourise nudity and sex, others are critical 
of the LGBT practices. In other words, their video films treat homosexuals as a minority that need to conform to the dictates of a heterosexual dominant in Nigeria. I conclude that while the contention on the construction of sexual orientation continues, individual right to life should also be considered in the creation of laws that prohibit non-straight sexual practices. 


\section{References}

Adichie, C. (2014). Chimamanda Adichie: Why can't he just be like everyone else? Retrieved 14th August, 2018 from http://www. thescoopng.com/2014/02/18/chimamanda-adichie-why-cant-hejust-be-like-everyone-else/

Cover, R. (2001). First contact: Queer theory, sexual identity, and mainstream film. International journal of sexuality and gender studies, Vol. 5 (1): 71-89

Criminalisation of Homosexuality. Retrieved 14th August 2018 from http://www.humandignitytrust.org/uploaded/Map/Country Reports/Nigeria.pdf 2015

Devine, T. (1998). Homosexuality: biologically or environmentally constructed. Retrieved 12th August, 2018 from http://jirscience. wcp.muohio.edu/ResearchHNatureProposalsArticles/ Homosexuality.biologicall.html

Gay beaten to death in Ondo State. (2018). Retrieved 12th August, 2018 from https://www.naij.com/763127-shocking-gay-man-beatendeath-ondo-state-photo.html

Harsin, S. (1991). Pathfinder: Developing a male gay identity. Collection Building, 11(4): 31-36

Ibanga, D. (2017). Scientific research on homosexuality and its philosophical implications:Plus the roles of parenting and "Okonkwo Complex" in sexual identity development. IOSR Journal of Humanities and Social Science. Vol. 22(6): 6169. Retrieved $3^{\text {rd }}$ November, 2020 from https://www.researchgate. net/profile/Diana_Abasi_Ibanga/publication/318056771

Kertbeny, B. (1869). Des Preussichen Strafgesetzebuchesvom Leipzig: Paramount Publishers.

Men in Love. (2010). John Dumelo, Muna Obiekwe and Tonto Dike. [Directed by Moses Ebere]

Novak, A. (2018). Capital punishment in precolonial Africa: The authenticity challenge. The Journal of Legal Pluralism and Unofficial Law. Vol. 50 (1): 71-93

Osewa, O. (2018). Charley Boy becomes a gay rights activist. Nairaland Forum. 2018. Retrieved 22nd July, from http://www.nairaland. com/4631887/charly-boy-becomes-gay-rights

Okuefuna, O. (2016). LGBT and the law: Protecting the rights of minorities in Nigeria. A MastersThesis submitted to MDP in Economic and Resources Law, University of Eastern Finland

Sivertson, K. (2016). Homosexuality in Perspective A Critical Discourse Analysis of the International Debate on Homosexuality in Uganda. A Maters thesis submitted to the University of Oslo. 
Okpadah, S. O./Queering the Nigerian Cinema and Politics of Gay Culture

Vivian, J. (2005). The media of mass communication. Boston: Pearson Education Inc.

Watson, A. (1974). Legal Concepts: an Approach to Comparative Law Georgia: University of Georgia Press. 